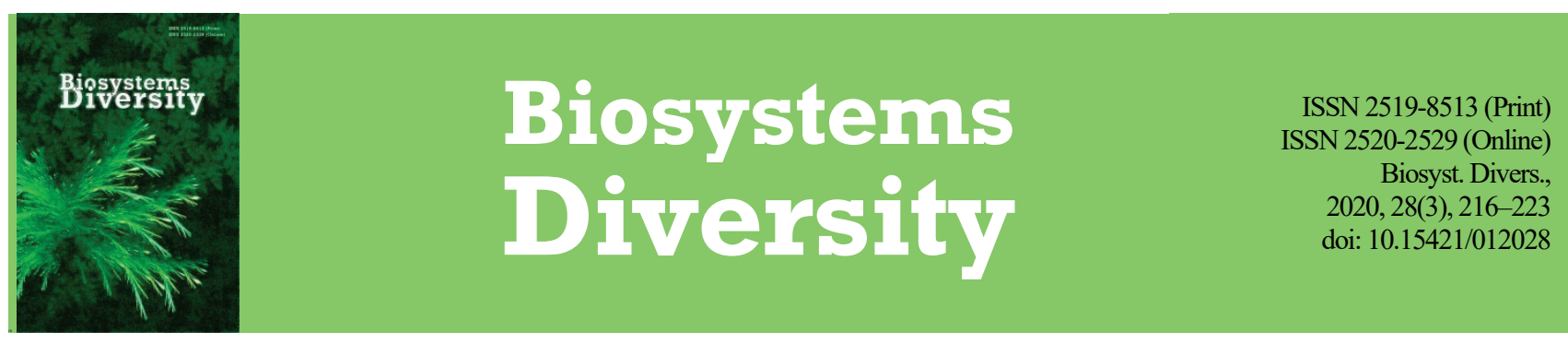

\title{
The role of ecological groups in the formation of cyanobacterial communities in the ecosystems of the North Azov region (Ukraine)
}

\author{
A. M. Solonenko*, L. I. Arabadzhy-Tipenko*, O. M. Kunakh**, D. V. Kovalenko* \\ *Bogdan Khmelnitsky Melitopol State Pedagogical University, Melitopol, Ukraine \\ **Oles Honchar Dnipro National University, Dnipro, Ukraine
}

Article info

Received 19.06.2020

Received in revised form 01.08 .2020

Accepted 03.08.2020

Bogdan Khmelnitsky

Melitopol State Pedagogical

University, Hetmanska st.,

20, Melitopol,

72318 Ukrain

Tel.: +38-098-558-37-55.

E-mail:anatol8@ukr.net

Oles Honchar

Dnipro National University

Gagarin av., 72,

Dnipro, 49000, Ukraine.

Tel.: +38-098-858-23-79.

E-mail:

kunah_olga@ukr.net

\begin{abstract}
Solonenko, A. M., Arabadzhy-Tipenko, L. I., Kunakh, O. M., \& Kovalenko, D. V. (2020). The role of ecological groups in the formation of cyanobacterial communities in the ecosystems of the North Azov region (Ukraine). Biosystems Diversity, 28(3), 216223. doi:10.15421/012028
\end{abstract}

The role of Cyanoprokaryota ecological groups in the ecosystems of the North Azov region was revealed in this work. On the territory of Pryazovskyi National Nature Park, 9 experimental polygons were studied, which covered steppe areas or slopes, salt marshes, coastal sandy soils and water bodies (rivers, lakes, estuaries, sea bays, lagoons). As a result of research on the territory of Pryazovskyi National Nature Park, 124 species of cyanoprokaryotes were identified, which include 127 intraspecific taxa. It was proved that the procedure of canonical correspondence analysis is the most suitable for the analysis of the species matrix. The axes identified as a result of the ordination procedure, which indicate the coordinated dynamics of the species, correlated with both synecological characteristics, such as diversity indicators, and with autoecological characteristics, such as ecotypes of cyanoprokaryotes in relation to habitat types or types of adaptation to salinity conditions. The first four canonical axes together explain $47.5 \%$ of species matrix variability. Canonical axis 1 explains $18.0 \%$ of the variability of the species matrix and is mostly marked by aqual subaerophytes and eurybionts. This axis indicates the presence of a gradient of salinity conditions where the most saline conditions correspond to the positive values of the axis, and the negative values correspond to less saline. Canonical axis 2 describes $12.1 \%$ of species matrix variability. This axis differentiates aquatic ecosystems from others. Canonical axis 3 explains $10.0 \%$ of the communities' variability. This axis distinguishes freshwater ecosystems from saline ecosystems. Markers of freshwater communities are stenotopic halotolerants, which are narrow-range, common mainly in the temperate zone of Europe. The canonical axis 4 explains $7.3 \%$ of variability of the matrix of species and is able to differentiate sand ecosystems. The ecotopic structure and geographic range width of community species have the greatest independent value among the considered sources of variation. The independent role of adaptation to the salinity conditions of the ecotope and the role of the type of ecosystems is somewhat smaller. The interaction between the sources of variation is important in the variation of the structure of communities. The interaction between the ecotopic structure and the geographic range width of species and the triple interaction between the ecotopic structure of a community, the width of the geographic range of species and the ecosystem type plays the greatest role in the variation of community structure. Ecotopic groups, which indicate the preference of a particular habitat, correlate with the species composition of the communities. It is shown that the ratio of ecototopic groups in a community is a characteristic that reveals the features of the community as a whole.

Keywords: diversity; ecological groups; environmental gradients; geographical range; variation partitioning.

\section{Introduction}

Cyanoprokaryota (or Cyanophyceae) is a group of ubiquitous prokaryotic organisms that have a high ecological plasticity, which enables them to inhabit different, often even extreme, habitats (Pelechata et al., 2016). Cyanophyta are very widespread: in seas, rivers and hyperhaline waters, in soils, on snow and ice, in hot springs, in aerophyte conditions, etc. (Hoffman, 1999; Liu et al., 2016). Cyanophyta are extremely tolerant of extreme conditions on the planet (Rampelotto, 2013). In model experiments, the blue algae stayed alive in the temperature range from -195 to $+130{ }^{\circ} \mathrm{C}$ (Inoue et al., 2001; Červený et al., 2015), pressure from 0.05 to $300 \mathrm{~atm}$ (Qin et al., 2014; Kitahara et al., 2019), and can withstand exposure to $160 \mathrm{kR} / \mathrm{hr}$ of radioactive cobalt (Microcoleus vaginatus - up to 1280 kR/hr) (Kraus, 1969; Yatagai \& Ishioka, 2014; Badri et al., 2015; Varshney et al., 2015). Blue algae play a planetary role in nitrogen balance (Jiang et al., 2017; Zhang et al., 2018). This is due to the ability of Cyanophyta's representatives to absorb nitrogen directly from the atmosphere (Bothe et al., 2010). The phenomena of restoration of soil fertility, preservation of fertility of virgin soils (Pankratova, 2006; Singh et al., 2016; Chittora et al., 2020), productivity of biohydrocenoses of the World Ocean (Flombaum et al., 2013; Hamilton et al., 2016; Fuchsman et al., 2019) are connected with nitrogen fixation activity of blue-green algae.
Among Cyanophyta there are extremely harmful species which are the causative agents of "blooming" of water (Bláha et al., 2009; Brookes \& Carey, 2011; Carey et al., 2012; Coad et al., 2014; Rastogi et al., 2015). During blooming, the oxygen regime deteriorates sharply, the decomposition products of dead cells enter the water, living individuals emit toxic substances (Davidson et al., 2014; Rastogi et al., 2015; Walter et al., 2018; Kimambo et al., 2019). Factors contributing to the development of "blooming" are high water temperature $\left(+23 \ldots+32^{\circ} \mathrm{C}\right)$, high concentration of nutrients (nitrogen, phosphorus, potassium), and lack of mixing of water masses (Codd et al., 2005; Posch et al., 2012; Backer et al., 2015; Zhang et al., 2016; Lürling et al., 2018; Kimambo et al., 2019).

Cyanobacteria are known from a wide range of water bodies - from oligotrophic to eutrophic. Much attention has been focused on determining the role of cyanobacteria as indicators of the eutrophication process. Particular attention is paid to eutrophic and hypertrophic lakes, where cyanobacterial blooms are caused by potentially toxic, often invasive, species (Nixdorf \& Deneke, 1997; Wiedner et al., 2002; Kokociński et al., 2010). A lot of interest in this problem is related to the negative effects of cyanobacterial bloom (Codd et al., 1999; Lopes \& Vasconcelos, 2011). Cyanobacteria are a permanent element of the phytoplankton communities in lakes of low trophicity, where they usually have little importance in the community structure. However, some data show the dominance of the 
cyanobacteria in oligotrophic lakes (Callieri \& Stockner, 2000) or oligomesotrophic lakes (Napiórkowska-Krzebietke \& Hutorowicz, 2013; Dadheech et al., 2014). In eutrophic lakes and water reservoirs, the domination of cyanobacteria in phytoplankton usually occurs in summer or autumn (Sommer et al., 1986). Strong eutrophic or hypertrophic waters show cyanobacterial domination regardless of season (Zohary \& Breen, 1989; Wagner \& Adrian, 2009; Beversdorf et al., 2015). Cyanobacteria species show different optimums with respect to environmental parameters such as temperature, light or nutrient content. Cyanobacteria are very well adapted to conditions of nutrient deficiency and limited availability of underwater light (Reynolds, 1984). The effect of nutrient concentrations on the development of blue-green algae is well documented, especially in terms of nitrogen $(\mathrm{N})$, phosphorus $(\mathrm{P})$ and the $\mathrm{N}$ to $\mathrm{P}$ ratio (Smith, 1983; Berman, 2001; Downing et al., 2001).

The concept of functional groups was proposed to describe the structure and dynamic of phytoplankton (Reynolds et al., 2002; Padisák et al., 2009). For phytoplankton, species from similar habitats and with similar sensitivity to environmental factors were classified in one functional group. The freshwater phytoplankton species were distributed among 31 functional groups (Costa et al., 2009). Phytoplankton functional groups have been used to study the impact of changes in the aquatic environment on the physiological, morphological and ecological characteristics of phytoplankton in different rivers, lakes and waters around the world (Becker et al., 2009, 2010; Kruk et al., 2017; Rodrigues et al., 2018). The application of the methods of classifying the functional groups of phytoplankton in aquatic ecosystems provides the key data reflecting dynamics of phytoplankton communities (Santana et al., 2017; Cupertino et al., 2019; Yao et al., 2020).

The north-western coast of the Sea of Azov is a set of natural systems that are characterized by a high level of biological diversity, economic value and have a high recreational potential (Maltseva et al., 2019; Yorkina et al., 2019). Harmonization of the goals of nature protection, optimization of economic efficiency and maintenance of recreational value is an extremely complex scientific and scientific-practical task. The development of a strategy for the rational use of nature should be based on the study of natural complexes that are within the protected areas as reference areas. In addition to the role of markers of the level of biological diversity, the objects of the nature reserve fund act as factors of functional stability of natural complexes in general. Therefore, the establishment of patterns of formation of Cyanoprokaryota communities in Priazovsky National Nature Park is an important scientific problem. In this paper, we consider the hypothesis that ecological groups of cyanoprokaryotes, established by different criteria, are a source of information that can explain the structure of their communities depending on environmental conditions.

\section{Methods}

Characteristics of experimental polygons. The research was conducted within Pryazazovsky National Natural Park. The park area is located in the coastal strip of the Sea of Azov and includes the aqual (coastal part of the Azov Sea, estuaries, bays, channel and floodplain of small rivers, their mouths, small artificial reservoirs) and terrestrial (coastal spits, the coast, significant sized land plots in river flood plains, areas of well-drained plakor land, areas with primary steppe vegetation, small groupings of shrubs and tree plantations) landscape complexes (Vorovka, 2011). There were 9 experimental polygons in the territory of Pryazazovsky National Natural Park which embraced steep areas or slopes, saline areas, coastal sandy soils, and water bodies (rivers, lakes, limans, sea bays, lagoons).

Polygon No 1: Tashchenaksky Pod (4639'29" N 3516'14" E) is an ornithological reserve of local significance. Area is 370.4 hectares. It is a flat depression area of the estuary of the drying out Taschenac River, which flows into the Molochny Estuary. Tashchenaksky Pod is an important place of nesting and resting of the wetlands bird complex. At the polygon, the samples were taken on steppe slopes, salt marshes, sandy alluvial soils along the Molochny Estuary, and estuary waters with salinity of $25-39 \%$. The length of the sampling profile is $400 \mathrm{~m}$.

Polygon No 2: the River Maly Utljug (463' $07^{\prime \prime}$ N $35^{\circ} 12^{\prime} 42^{\prime \prime}$ E). It is a small steppe river that flows into the Utljug Estuary. The polygon is located near the village Shelyugi. The width of the river at the sampling sites is $30-35 \mathrm{~m}$, depth up to $2 \mathrm{~m}$. The banks of the river are overgrown with reeds. The profile covers only the water body.

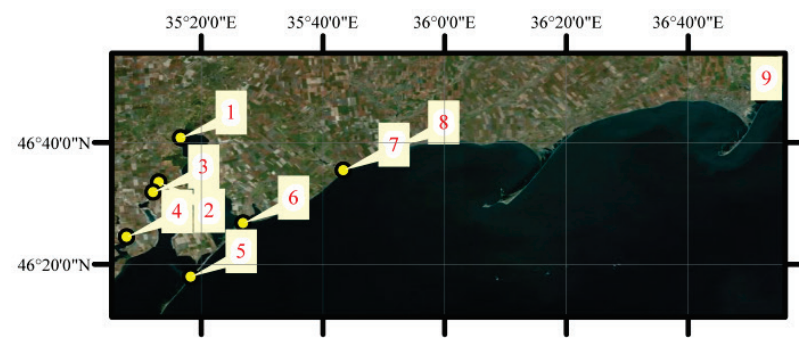

Fig. 1. A map of the locations of the scientific polygons in the research area: 1 - Tashchenaksky Pod, 2 - the River Maly Utljug, 3-the Upper Utljug Estuary, 4- the Sivashik Estuary, 5-Fedotova Spit,

6-the Stepanovska Spit, 7 -the Tubalsky Estuary, 8-the mouth of the Korsak River, 9 - the floodplain of the Berda River

Polygon No 3: Upper part of the Utljug Estuary (46 30'41" N $\left.35^{\circ} 11^{\prime} 09^{\prime \prime} \mathrm{E}\right)$. It is a complex nature monument of national importance, with an area of 280 hectares. The research polygon is located at the mouth of the River Maly Utljug and occupies its right bank. The polygon includes a steppe slope, a salt marsh, and a brackish water body. The length of the sampling profile is $350 \mathrm{~m}$.

Polygon No 4: the Sivashik Estuary $\left(46^{\circ} 24^{\prime} 28^{\prime \prime}\right.$ N $35^{\circ} 06^{\prime} 09^{\prime \prime}$ E) is a landscape reserve of national importance with an area of 2800 hectares. It is a brackish water body which has a connection with the Sea of Azov and the coastline (steppe slopes which pass into saline meadows and salt marshes). In summer, the upper part of the estuary dries out and the lower part is covered with a self depositing salt layer. The salinity of the estuary ranges $17-28 \%$ and in the drying lagoons of the estuary to $120 \%$. The polygon is located on the right bank of the estuary. The sampling profile is $360 \mathrm{~m}$ and includes steppe slopes, salt marshes, water estuary.

Polygon No 5: Fedotova Spit (46 $17^{\prime} 14^{\prime \prime}$ N 35 $15^{\circ} 7^{\prime} 38^{\prime \prime}$ E) is a landscape reserve of national importance occupying 1910 hectares. The spit is represented by sand-seashell sediments of accumulative origin and stretches almost $30 \mathrm{~km}$ to Biruchy Island, the width of the spit ranges $360-800 \mathrm{~m}$. The scientific polygon is located near the village of Stepok. The length of sampling profile is $540 \mathrm{~m}$, from the Utljug Estuary to the sandy alluvial bars of the Azov Sea. The profile includes the water of the Utljug Estuary with salinity of 8-11\%o, steppe vegetation and sand soils.

Polygon No 6: Stepanovska spit (462 $27^{\prime} 06^{\prime \prime}$ N $35^{\circ} 28^{\prime} 33^{\prime \prime}$ E) is a landscape reserve of local significance, with an area of 200 hectares. The spit separates the Molochny Estuary from the Sea of Azov. The scientific polygon covers the waters of the Molochny Estuary (25-40\%), the salt marshes of the Molochny Estuary shore, and the sandy soils of the alluvial bar along the Sea of Azov. The length of the sampling profile is $340 \mathrm{~m}$.

Polygon No 7: the Tubalsky Estuary (46 $\left.35^{\prime} 28^{\prime \prime} \mathrm{N} 35^{\circ} 42^{\prime} 56^{\prime \prime} \mathrm{E}\right)$. It is a flat depression at the mouth of the drying river that flows into the Sea of Azov. The scientific polygon is located near the right slope in an area of temporary salty ponds. Temporary water bodies are separated from the Sea of Azov by a sandy shore $200-250 \mathrm{~m}$ wide. The sampling profile is $350 \mathrm{~m}$ and includes steppe slopes, salt marshes, alluvial sandbars of the Azov Sea and saline water bodies with the mineralization of $34 \%$.

Polygon No 8: the mouth of the Korsak River $\left(46^{\circ} 38^{\prime} 38^{\prime \prime}\right.$ N $\left.35^{\circ} 51^{\prime} 28^{\prime \prime} \mathrm{E}\right)$. Is a flat part of the territory of the Korsak River floodplain. The floodplain is periodically flooded with the waters of the Azov Sea. In the surrounding areas a temporary shallow saline water body forms. The level of mineralization in these water bodies ranges from $14-40 \%$. The surrounding area is represented by saline vegetation. The sampling profile is $352 \mathrm{~m}$ from the right slope to the Azov Sea and includes a steppe slope, salt marshes, salty temporary lakes and a sandbar along the sea.

Polygon No 9: the floodplain of the Berda River $\left(46^{\circ} 47^{\prime} 49^{\prime \prime} \mathrm{N}\right.$ $36^{\circ} 52 ' 24^{\prime \prime} \mathrm{E}$ ) is a landscape reserve of national significance of 1417 hectares. It is a flat area with thickets of reeds and meadow-halophilic vegetation. The scientific polygon includes steppe slopes, saline meadows, salt marshes, and mineralized temporary ponds with salinity of $12-15 \%$. Sampling profile is $660 \mathrm{~m}$. 
Methods of collection and processing of soil algological samples. 124 algological individual and combined water and soil samples served as the study material. The individual samples were selected to determine macroscopic differences on the surface of the soil or in the aquatic environment. The sample was carried out in nine defined scientific polygons in the spring-winter period during the 2013-2019 exploratory route studies. The coordinates of each polygon were defined using the GPS (Garmin GPS 12 MAP) browser. The polygons were selected in several sequences for each biotope (steep slope, salt, sandy littoral zone, water body). The material was collected according to the generally accepted basic algorithm by a sterile method (Hollerbach \& Stina, 1969). Soil was collected in paper envelopes that were previously heated in a drying cabinet at 130-150 degrees for an hour. The collection of the soil was performed using a spatula that was sterilized directly in the sites of the selection: the instrument was wiped in spirit and then plunged into the research soil repeatedly. The samples were processed fresh for 1-2 days from the moment of selection, and dried in a dark place to dry air condition and kept for further processing for several months.

Material and methods of collection and study of water-algological samples. The water samples were collected in temporary waters, salt lakes, estuaries and rivers. Mostly sampling was carried out in shallow water up to $1 \mathrm{~m}$ depth, as the studied water bodies did not have significant depths. Therefore, sampling was carried out by hydrobiological methods of sampling phytoplankton and phytobenthos. Also, in cases of intensive development of algae on the surface of the water body and in the benthos, individual samples were collected. Phytoplankton was selected by filtration of water through a planktonic mesh. 50-100 liters of water from the surface layer of $15 \mathrm{~cm}$ was poured through the planktonic mesh, after which the water sample was collected in labeled sterile glass containers. When collecting plankton of surface water layers, the planktonic mesh was lowered into the water so that the upper hole of the net was $5-10 \mathrm{~cm}$ above its surface.

Ecological and areological groups of Cyanoprokaryota. In relation to preferential environment, cyanoprokaryotes were divided into aerobionts, aquatic organisms, amphibionts, and terabionts. Teratobionts or terrestrial forms are in turn divided into edaphobionts, aerophytes and subaerophytes (Vinigradova, 2012). Subaerophytes include aquatic and out of water forms of cyanoprokaryotes, which are characterized by high ecological valence. Cyanophyceae form transitional ecological groups according to the preferential type of habitat, namely aerophytes, aqual, aqua-subaerophytic, aqua-terrestrial, eurybionts, subaerophytes, terrestrial forms, terrestrial-subaerophytic forms. Amphibiont forms include aqua-subaerophytic, subaerophytic, and terrestrial-subaerophytic forms. Such species can exist in both aquatic and terrestrial environments. Aqual forms occur exclusively in the aquatic environment. Terrestrial forms inhabit the soil and aerophytes which are adapted to exist in conditions of moisture deficiency (Vinigradova, 2012).

The following ecological groups among Cyanobacteria are selected in relation to the level of environmental salinity (Komárek \& Anagnostidis, 1999). Halotolerant is a species that exists in habitats with normal $(0-30 \%)$ or increased salt concentration. Halobiont is a species that exists in habitats with a high (31-60\%) or very high (70-330\%) salt concentration. Halophiles prefer habitats with a high concentration of salt. The marine species live on the coast of the sea and ocean. In relation to salt, marine species take a transitional position between halotolerants and halophiles (Vinigradova, 2012). According to the spatial coverage of species geographic ranges, cyanoprocariotes can be divided into the following groups: European moderate zone residents, European species, Eurasian species, Circumcontinental or Circumoceanic and Cosmopolitan (Vinigradova, 2012).

The dependence between species and genus numbers in communities can be described by a linear model (Palmer et al., 2008):

$$
\log (\text { Species })=\mathrm{b}_{0}+\mathrm{b}_{1} \log (\text { Genera })+e \text {, }
$$

where "Species" is the number of species, "Genera" is the number of genera, $b_{0}$ and $b_{1}$ are regression coefficients. The residuals of the regression model $e$ were considered to be the index of the taxonomic ratio species/genus.

Methods of ordination of communities. Multidimensional ordination techniques were used for analyzing spatial-temporal variation in the spe- cies composition of the invertebrate complex. The data matrix was subjected to Correspondence Analysis (CA), Constrained Correspondence Analysis (CCA) and Constrained Redundancy Analysis (RDA) in order to extract the most important patterns of community variation (Legendre et al., 2005). The environmental factors were fitted into the CA-ordination axes by means of the enfit function from the vegan library (Oksanen et al., 2018). The Detrended Correspondences Analysis (DCA) was used to distinguish whether the species response to environment factors is predominantly monotonous or mostly unimodal. To do this, the length of the first most important gradient of the community variation was assessed (Ter Braak \& Prentice, 1988). If the gradient length exceeds more than 2 standard deviations, then Constrained Correspondence Analysis (CCA) should be chosen as the routine procedure. Otherwise, Constrained Redundancy Analysis (RDA) is more appropriate. For statistical calculations, we used appropriate procedures for Statistica (Version 12.0, StatSoft Inc., www.statsoft.com) or R (version 3.5.2; R Core Team, 2018).

\section{Results}

As a result of our research within the territory of Pryazazovskyi National Natural Park, 124 species of Cyanoprokaryota were found which include 127 intraspecies taxa. The largest axis extracted after Detrended Correspondences Analysis equalled 6.0, indicating that the Constrained Correspondence Analysis procedure is the most suitable for the ordination of the species matrix. The first four canonical axes are able to explain $47.5 \%$ of the species matrix variability (Table 1). The canonical axis 1 explains $18.0 \%$ of variability of the species matrix and is most marked by the aquatic-subarerophytes (positive values) and eurybionts (negative value, Fig. 2a). The positive axis values correspond to communities with the higher diversity, especially the species/genus ratio. This indicates the presence of a gradient of the salinity regimes where the most saline conditions correspond to the positive axis values, and negative ones are less saline. So it is only natural that there are water and salt ecosystems in the area of higher canonical axis 1 values, and there are steppe and sand ecosystems in the area of negative ones. The conditions for higher salinization are more favourable for species with a wide geographical range. The conditions with less or no salinization are more favourable for Cyanoprokariotes species with a European range. Canonical axis 2 explains $12.1 \%$ of the species matrix variability. This axis differentiates the aquatic ecosystems (positive axis values) from the others (negative axis values). The consequence of this is that aquatic species positively correlate with the canonical axis 2. Other species, except for aqual-subaerophytes, whose correlation coefficient statistically does not significantly differ from the null alternative, negatively correlate with the canonical axis 2 . Water ecosystems are characterised by lower rates of diversity, but by a high species/species ratio. Ecological groups of cyanoprokariotes in terms of response to salinization do not form a clear pattern so one can assume that correlative relationships are focused on community relationships and not directly on external influences.

Analysis of the configuration of ecological factors and synecological indicators in the space of the first two canonical axes allows us to obtain a comprehensive picture of the ecological structure of the cyanoprokaryotic communities. Communities of aquatic ecosystems occupy the upper right quadrant of the plane that is defined by these two axes and are marked with aqual forms of Cyanoprokaryota. The counterclockwise movement from this quadrant sequentially moves us from aqua-subaerophytic forms to subaerophytic ones. The closest biotope marker to this area is salt marshes, but the corresponding zone is very wide, which indicates a significant floristic heterogeneity of salt marsh communities. The right side of the considered area corresponds to more saline stations, the left - less saline. Solonchak communities occupy the area from highly saline to moderately saline. Communities with a predominance of subaerophytes are characterized by higher species diversity and form a special kind of salt marsh flora. It is formed under conditions of moderate salinity and mainly by representatives of Eurasian species. It should be noted that saline conditions are most often inhabited by species with a wide geographical distribution, especially cosmopolitans.

The lower right quadrant is the zone of the greatest diversity of communities both in terms of the number of species and the number of genera. 
These two indicators of diversity are characterized by consistent dynamics. The canonical Axis 3 explains $10.0 \%$ of the community variability. This axis distinguishes freshwater ecosystems (right side of the Fig. $2 b$ ) from the saline ecosystems (left side). Accordingly, steppe communities occupy the central part of the space, which is set by the canonical axes 3 and 4. It is natural that the markers of freshwater communities are the stenotopic halotolerants. These species also have mainly narrow ranges within the temperate zone of Europe. The canonical axis 4 explains $7.3 \%$ of the variability of a species matrix. The negative value of this axis denotes sand ecosystems. The results of the ordination indicate that communities in sandy soils tend to be represented by wide-ranging species.

Table 1

Correlation of external predictors and canonical axes

\begin{tabular}{|c|c|c|c|c|c|c|}
\hline Predictors & \multicolumn{4}{|c|}{ Canonical Axes, $\%$ explained inertia } & $R^{2}$ & $\operatorname{Pr}(>r)$ \\
\hline \multicolumn{7}{|c|}{ Ecotypic groups } \\
\hline $\mathrm{Aq}$ & 0.40 & 0.67 & 0.62 & 0.01 & 0.72 & 0.001 \\
\hline AqSA & 0.89 & 0.01 & -0.33 & -0.30 & 0.41 & 0.001 \\
\hline SA & 0.52 & -0.71 & -0.30 & 0.36 & 0.56 & 0.001 \\
\hline TrSA & -0.72 & -0.46 & -0.46 & 0.23 & 0.59 & 0.001 \\
\hline $\mathrm{AqTr}$ & -0.71 & -0.46 & -0.51 & -0.13 & 0.27 & 0.009 \\
\hline $\operatorname{Tr}$ & -0.52 & -0.68 & -0.50 & -0.13 & 0.40 & 0.001 \\
\hline $\mathrm{Ae}$ & -0.41 & -0.69 & -0.51 & 0.31 & 0.29 & 0.004 \\
\hline$\underline{\mathrm{Eu}}$ & -0.95 & -0.17 & 0.20 & -0.18 & 0.57 & 0.001 \\
\hline \multicolumn{7}{|c|}{ Diversity indexes } \\
\hline Species & 0.48 & -0.80 & -0.25 & 0.27 & 0.22 & 0.032 \\
\hline Genus & 0.10 & -0.99 & 0.00 & -0.06 & 0.26 & 0.012 \\
\hline Resid & 0.71 & 0.48 & -0.25 & 0.45 & 0.59 & 0.001 \\
\hline \multicolumn{7}{|c|}{ Ecological groups in the salinity gradient } \\
\hline$\overline{\mathrm{H} 1}$ & -0.75 & 0.34 & 0.53 & 0.21 & 0.78 & 0.001 \\
\hline $\mathrm{H} 2$ & -0.87 & -0.33 & -0.28 & -0.22 & 0.78 & 0.001 \\
\hline $\mathrm{H} 3$ & 0.97 & 0.22 & 0.01 & -0.06 & 0.82 & 0.001 \\
\hline $\mathrm{H} 4$ & 0.94 & -0.14 & -0.10 & 0.29 & 0.75 & 0.001 \\
\hline \multicolumn{7}{|c|}{ Geographic range width } \\
\hline$\overline{\text { G1 }}$ & -0.26 & 0.70 & 0.59 & 0.30 & 0.11 & 0.262 \\
\hline G2 & -0.93 & -0.25 & -0.25 & -0.06 & 0.62 & 0.001 \\
\hline G3 & 0.72 & -0.51 & 0.02 & 0.47 & 0.47 & 0.001 \\
\hline G4 & -0.84 & 0.15 & 0.44 & -0.27 & 0.22 & 0.032 \\
\hline G5 & 0.79 & 0.34 & -0.29 & -0.42 & 0.35 & 0.003 \\
\hline \multicolumn{7}{|c|}{ Biotopes (centroids coordinates) } \\
\hline Biotopes & - & - & - & - & 0.62 & 0.001 \\
\hline Sand & -0.64 & -0.52 & -1.05 & -0.69 & - & - \\
\hline Solonchak & 0.24 & -0.21 & -0.63 & 0.15 & - & - \\
\hline Steppe & -0.52 & -0.64 & 0.50 & 0.07 & - & - \\
\hline Water & 0.78 & 1.22 & 1.26 & 0.00 & - & - \\
\hline
\end{tabular}

Note: Aq - aqual; AqSA - aqual-subaerophytic; SA - subaerophytic; TrSA terrestrial-subaerophytic; AqTr - aqua-terrestrial; $\mathrm{Tr}$ - terrestrial; Ae - aerophytic; $\mathrm{Eu}$ - eurybiont; Species - number of species; Genus - number of genus; Resid detrend ratio of species/genera; H1 - halotolerant (stenotopic); H2 - halotolerant (eurytopic); H3 - halobionts; H4 - halophiles; G1 - range within the Europe temperate zone; G2 - European; G3 - Eurasian; G4 - Circumcontinental or Circummoceanic; G5-Cosmopolitans.

Inertia unexplained by the ecological predictors is characterized by $\chi^{2}$, which is equal to 1.353 , which corresponds to $47.2 \%$ of the total inertia of the species matrix. Thus, the ecological predictors, which were chosen for analysis, well explain the variation of the Cyanoprokaryota community structure. The fractionation of the $\chi^{2}$ statistic showed that among the examined sources of variation, both the ecotopic structure of the community (explains $\chi^{2}=0.243$, or $8.5 \%$ of the total inertia) and the width of the range (explains $\chi^{2}=0.175$, or $6.1 \%$ of the total inertia) have the greatest independent importance to explain community structure. The independent importance of the adaptation to the salinity conditions and ecosystem type is slightly lower $\chi^{2}=0.077$, or $2.7 \%$ of total inertia and $\chi^{2}=0.041$, or $1.5 \%$ of total inertia, respectively). The interaction between the sources of variation is important in the variation of the structure of community. The largest role in variation of the community structure is played by the interaction between the ecotopic structure and width of species ranges $\left(\chi^{2}=\right.$ 0.395 , or $13.8 \%$ of total inertia) and the triple interaction between the ecotopic structure of the community, the width of species ranges and ecosystem type $\chi^{2}=0.266$, or $9.3 \%$ of total inertia).
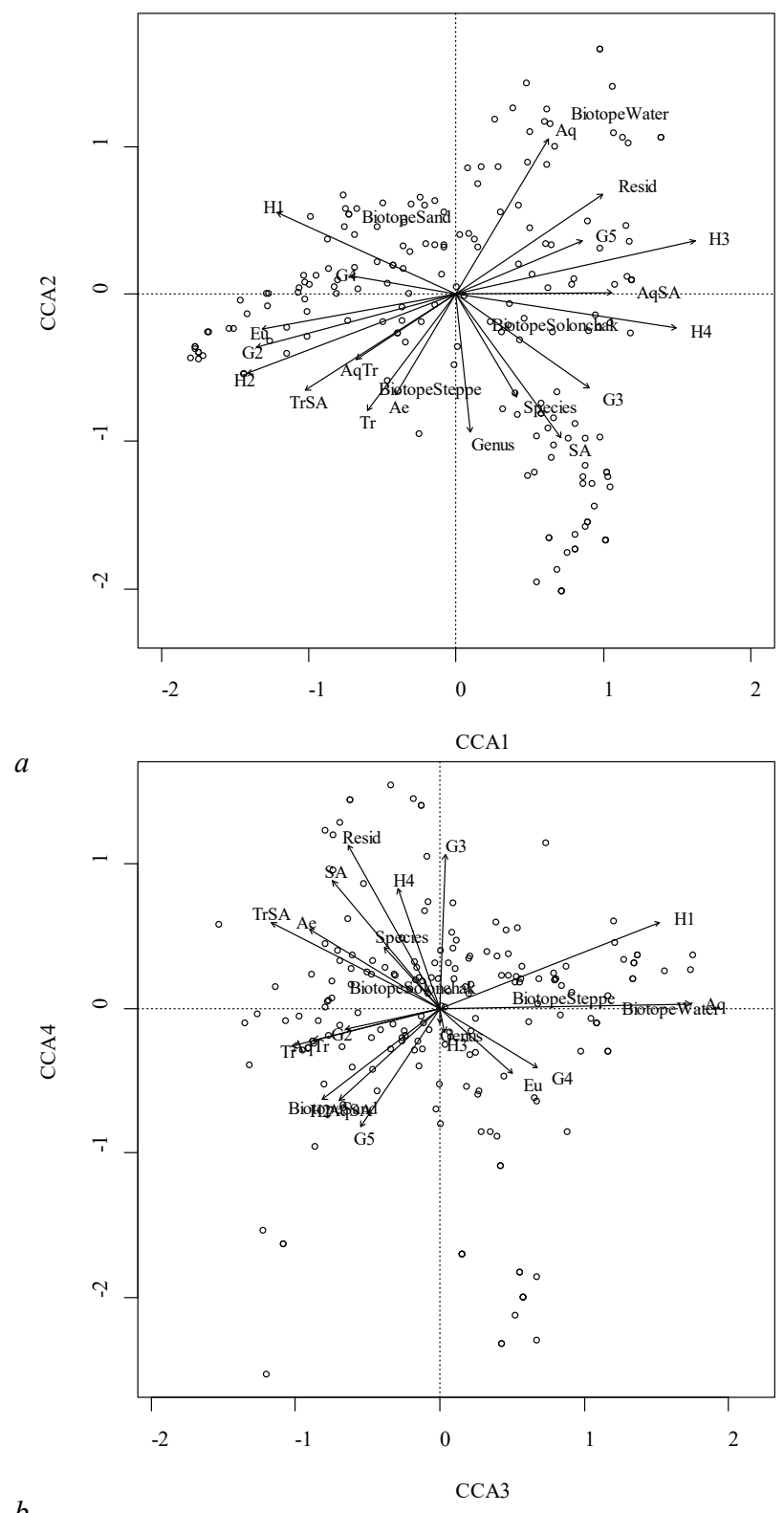

Fig. 2. Location of cyanoprokaryotic communities in the space of canonical variables 1 and $2(a)$ and 3 and $4(b)$ and assessment of the impact of ecological variables on communities: Cyanoprokaryota species are presented by points; arrows show ecological variables: Aq-aqual; AqSA - aqual-subaerophytic; SA - subaerophytic; TrSA - terrestrialsubaerophytic; AqTr - aqua-terrestrial; $\mathrm{Tr}$ - terrestrial; $\mathrm{Ae}$ - aerophytic; $\mathrm{Eu}$ - eurybiont; "Species" - number of species; "Genus" - number of genera; Resid - species/genera detrended ratio; $\mathrm{H1}$ - halotolerant (stenotopic); $\mathrm{H} 2$ - halotolerant (eurytopic); H3 - halobionts; H4 - halophiles; G1 - area within the temperate zone; G2 - European; G3 - Eurasian; G4 - Circumcontinental or Circumoceanic; G5 - Cosmopolitans

\section{Discussion}

The main challenge for ecology is to identify the determinants of the structure of environmental communities (Gilbert \& Bennett, 2010). Our study covers a wide range of ecosystem types - from steppe to aquatic ecosystems. The Detrended Correspondence Analysis indicates that the species of which the Cyanoprokaryota community consists are representted within significant environmental gradients in such a way that the form of the function of their response to the impact of environmental factors is mostly unimodal. For this type of data, Canonical Correspondence Analysis is most appropriate. A list of community ecological characteristics calculated on the basis of the autecological parameters of the 
Cyanoprokaryota species was used for the explanatory variables. This approach allows us to test the hypothesis that the autoecological parameters of the Cyanoprokaryota species are important for the formation of the community structure. In our study, it was shown that the axes extracted as a result of the ordination procedure, which indicate the coordinated dynamics of species, correlate with both synecological characteristics, such as diversity indicators (species and genus diversity and detrended species/genus ratio), and with autoecological characteristics, such as cyanoprokaryotic ecotypes in terms of habitat condition or salinity adaptation. Other studies have shown that within the region, diversity in the number of species and number of genera is characterized by a high level of correlation (Andersen, 1995). Genus diversity can be used as a surrogate for species diversity (Báldi, 2003) and species composition (Alves et al., 2016). There is an opinion that the use of the lower taxonomic resolution in taxonomic determination of plankton in combination with ecological classification can be used as a strategy to minimize difficulties in plankton identification (Machado et al., 2015). Our results suggest that only for part of the cyanoprokaryotic community can the genus level be a good approximation of species diversity.

That the number of species is an increasing function of the area is one of the most significant generalizations of the ecology (Arrhenius, 1921; Gleason, 1922; Fisher et al., 1943). No clear trends in the number of species and genera with geographical latitude have been found for the flora of North America, but the residuals of this model show a clear dependence on latitude (Palmer et al., 2008). Also an important result is that the direction corresponding to the variation of diversity, which is indicated by the number of species and genera, is orthogonal to the direction denoted by the detrended species/genus ratio. Orthogonality indicates the independence of variables which also indicates that the detrended species/genus ratio has specific information. The intensity of interspecies competition is regarded as a possible ecological interpretation of the species/genus ratio. A higher value of the ratio indicates a saturation of the community of taxonomically similar species, between which the intensity of interspecific competition is higher than between more taxonomically distant species (Enquist et al., 2002; Webb et al., 2002). According to such interpretation, the ecosystems with a high level of salinity (water or solonchak) are able to carry the largest number of species that can actively compete. It should be noted that cyanoprokaryote species in these ecosystem types are represented mainly by aqua-subaerophyte forms with a wide (cosmopolitan) range. In turn, there is a competitive exclusion of species that is labeled with a lower detrended species/genus ratio in the steppe or sandy ecosystems that are subjected to less salinity. These Cyanoprokaryota communities are represented by terrestrial or eurytopic species, the range of which predominantly covers Europe.

The key goal of experimental biology is to quantify the relationship between environment predictors and ecosystem response (Sokolov \& Zhukov, 2017). A statistical analysis that allows one to achieve this goal is called variation partitioning (Borcard et al., 1992; Legendre et al., 2005; Fischer, 2019). Our results confirm the importance of cyanoprocaryotic adaptations for living in certain environments as a community structuring factor. It is also worth noting the structuring role of species response types in the gradient of salinization conditions, as well as the width of species ranges. It is important not only to recognize the impact itself, but also to quantify it in comparison with other sources of variation. This task can be solved by variance partitioning (Borcard \& Legendre, 2002; Sattler et al., 2010; Shi et al., 2015; Tonkin et al., 2016; Astor et al., 2017). The variation partitioning procedure is used to weight balance between importance of the neutral and niche-dependent factors for community structuring (Smith \& Lundholm, 2010; Yorkina et al., 2018). The variation partitioning of a community is aimed at studying the beta diversity. The beta diversity characterizes variability in composition of species between sites in a geographic region (Zhukov et al., 2018). Beta diversity is a key concept for understanding the functioning of ecosystems, their protection and management (Legendre, 2007). The use of the redundancy analysis of and variation partitioning in communities of aquatic macrophytes allows one to estimate the relative importance of the local environment variables, climatic factors and spatial position (Alahuhta et al., 2018).

Analysis of the species list of a respective territory allows one to establish the ecological profile of its flora (Vinigradova, 2012). The basis of solonchak flora was shown to be formed by the species with a high adaptive potential such as amphibiont and terrestrial forms (Vinogradova, 2006). A significant information importance of the structure of the ecotopic groups was revealed to explain variations of species composition at the community level. The considerable adaptation potential of species contributes to the variability in species composition of cyanoprocaryotic communities within a particular ecosystem type. The diversity of conditions within ecosystems forms a wide variety of environmental regimes, according to which the species composition of the community changes. But the degree of freedom of such variability is restricted by the adaptation models, which can be specified by the spectra of ecotypic groups. This explains that the role of ecotypic diversity in the determination of species composition is more important than that of ecosystem types. Such variability of the Cyanoprokaryota communities allows us to consider this taxonomic group as a source of independent information, which does not repeat the bioindicative information from other sources.

The type of ecosystems is determined based on the material "macroscopic" parameters, such as relief, soil conditions, and vegetation structure represented by higher plants. The dynamics of the Cyanoprokaryota communities take place at another spatial and time level of ecosystems. Thus, the functional-hierarchical levels of organization of superorganismic systems form relatively independent space-time ecosystems, which differ in their spatial and temporal aspects of dynamics (Pokarzhevskii, 1996). The measure of temporal dynamics is ecological time (the duration of existence in units of astronomical time of one stage of succession dynamics) and time of complete biological cycle (time during which the flow of nutrients passing through the ecosystem becomes equal to their mass in ecosystem biomass) (Gongalsky, 2014). In terrestrial soil ecosystems there are bacterial-algae-protozoan (ecological time - up to 1 week, size - up to several centimeters), fungal-microarthropodic (ecological time - from 1 week to 1 year, size is commensurate with the rhizosphere of one plant) and lumbicide-plant (ecological time - from 1 month to decades, size within the biogeocenosis) (Pokarzhevskii, 1996). Similar spatio-temporal structuring can be performed for other living environments - aquatic, terrestrial and amphibiotic. Thus, according to the dimensional features, the spatio-temporal dynamics of cyanoprokaryotic communities causes their significant diversity within a particular type of ecosystem. Such diversity is the basis for obtaining specific information about the course of processes at the level of a particular ecosystem.

As sources of variation in the species composition of Cyanoprokaryota communities, we consider indicators that differ significantly in their nature. Ecotope groups and groups that characterize the preferences of species for the salinity conditions of ecotopes characterize the autecological strategies of species for adaptation to the conditions of existence. It is important to note that ecotopic groups that indicate preference for a particular habitat correlate with the species composition of communities. Thus, the correlation of ecotopic groups in a community is a characteristic that reveals the features of the community as a whole. This makes it possible to consider ecotypic spectra as a synecological characteristic of a Cyanoprocaryota community.

The important result is that with the width of geographic range of Cyanoprokaryota species, as quantitative indicators, correlate certain features of the structure of species ensembles. The problem of geographical range of species is key in modern integrative biology (Bozinovic \& Naya, 2015). There is a consensus in the idea that the boundaries of the distribution range of species are the consequence of complex relationships between the species specific physiological, phenological and ecological characteristics, as well as the ability to dispersion and environmental interactions between species (Bozinovic et al., 2011). A number of climate hypotheses were advanced to explain the variability in species ranges (Pither, 2003). The key idea is that variability of physiological properties along geographical gradients affects species tolerance (Spicer \& Gaston, 2009). Thus, the correlation of causes that affect the position of a species in a community and its geographical distribution is the reason why the community structure depends on the biogeographic features of the species that constitute it. Dispersion, geographical isolation, range limitation or expansion in the past, drifting processes, the originator's effect and the role of selection all leave their traces in the appearance and features of the geographical distribution of the modern cyanobacteria flora (van 
Gremberghe et al., 2011). There is a standpoint that there are no limitations to the geographical distribution of bacteria (Foissner, 2006). The lack of spatial structure in bacterial communities is confirmed by molecular data for soil (Fierer \& Jackson, 2006), marine (Mullins et al., 1995) and freshwater bacteria (Glockner et al., 2000; Van Der Gucht et al., 2007), including cyanobacteria (Jungblut et al., 2010). However, several studies have reported a clear spatial structure for other prokaryotes, including marine (Zwirglmaier et al., 2008), soil (Cho \& Tiedje, 2000) and freshwater bacteria (Pearson et al., 2009). For prokaryotes occurring under extreme conditions, such as hot volcanic vents or deep hydrothermal vents, the phytogeographic structure indicates effects of strong geographical isolation and limited distribution (Whitaker et al., 2003; Papke et al., 2003; Miller et al., 2007), although not all thermophilic cyanobacteria show a clear spatial structure (Ionescu et al., 2010). For more widely distributed bacteria, biogeographic patterns may be the result of historical (e.g., limiting distribution) and/or ecological processes (e.g., local selection) (Whitaker, 2006; Ramette \& Tiedje, 2007). The relative importance of these processes in the structuring of microbial systems has so far been little studied (Martiny et al., 2006). Apart from cosmopolitan species, taxa with more restricted distribution also exist among Cyanoprocaryotes. Many of them have a Holarctic or pantropical distribution. In addition to the distribution of ecological niches, temperature is one of the main control factors limiting the spread of Cyanoprocaryote species in certain latitudes. In addition, the presence of species with regional distribution (endemics) cannot be excluded, which points to the need to take into account other factors affecting the geographical distribution of Cyanoprocaryotes (Hoffmann, 1996). A relationship has been found between geographical distribution and ecological properties of Cyanoprocaryote species. Thus, for Cyanoprocaryotes of the Black Sea coast of Ukraine the proportion of cosmopolitans is higher among halobionts, marine and saltwater species. In turn, the number of European species and species of temperate latitudes is greater among aerophytes (Vinogradova \& Bryantseva, 2017).

The results show that not only among the total list of regional flora species is there an unequal ratio of representatives with different range width depending on the position of the species in the gradient of salinity conditions. It is shown that the composition of species of a particular community is due to the ecological properties of species, which also affect the overall geographical distribution of the species. The presence of ecological determinants which influence the geographical distribution as well as the success of a species in a particular community is confirmed by the statistically significant influence of the interaction of species range width and other factors of community variation, namely ecotopic specialization, preference of salinity conditions and habitat type. Thus, biogeographic characteristics of species, which are traditionally considered as flora characteristics within a large area, are an indicator that plays an important role in forming the structure of a particular plant community. This role is conditioned by the fact that the geographical distribution of a species depends on the autecological characteristics of the species, which also determine the success of the species in communities within the range.

\section{Conclusion}

Cyanoprokaryotes are represented by various communities in aquatic, terrestrial and amphibiotic ecosystems of the investigated area. The variation in species composition in Cyanoprokaryotes communities is driven by the peculiarities of ecological regimes of the environment and is conditioned by the diversity of ecosystem types. Variation of the Cyanoprocaryota species structure correlates with changes in the structure of ecotopic groups, ecological groups in the gradient of salinity conditions of ecotopes and with the width of species ranges. The communities of aquatic and terrestrial ecosystems are the most distinct among themselves. Aquatic ecosystems are distinguished by lower diversity, but high species/genus ratios. Aquatic communities are typically characterized by the dominance of aquatic and aquatic-subaerophyte species. Terrestrial and amphibious ecosystems are known to be characterized by higher prevalence of eurybionts. Solonchak ecosystems, as an amphibious habitat, are characterized by a significant diversity of conditions, so their Cyanoprokaryote communities are significantly diverse. Saline conditions are most often inhabited by species with wide geographical distribution, especially cosmopolitans. Specific conditions for Cyanoprocaryote life are formed in sandy soils. Communities in sandy soils tend to be represented by wide range species.

\section{References}

Alahuhta, J., Lindholm, M., Bove, C. P., Chappuis, E., Clayton, J., de Winton, M., Feldmann, T., Ecke, F., Gacia, E., Grillas, P., Hoyer, M. V., Johnson, L. B., Kolada, A., Kosten, S., Lauridsen, T., Lukács, B. A., Mjelde, M., Mormul, R. P., Rhazi, L., Rhazi, M., Sass, L., Sondergaard, M.,Xu, J., \& Heino, J. (2018). Global patterns in the metacommunity structuring of lake macrophytes: Regional variations and driving factors. Oecologia, 188(4), 1167-1182.

Alves, C., Vieira, C., Almeida, R., \& Hespanhol, H. (2016). Genera as surrogates of bryophyte species richness and composition. Ecological Indicators, 63, 82-88.

Andersen, A. N. (1995). Measuring more of biodiversity: Genus richness as a surrogate for species richness in Australian ant faunas. Biological Conservation, 73(1), 39-43

Arrhenius, O. (1921). Species and area. The Journal of Ecology, 9(1), 95.

Astor, T., von Proschwitz, T., Strengbom, J., Berg, M. P., \& Bengtsson, J. (2017). Importance of environmental and spatial components for species and trait composition in terrestrial snail communities. Journal of Biogeography, 44(6), 1362-1372.

Backer, L. C., Manassaram-Baptiste, D., LePrell, R., \& Bolton, B. (2015). Cyanobacteria and algae blooms: Review of health and environmental data from the harmful algal bloom-related illness surveillance system (HABISS) 2007-2011. Toxins, 7(4), 1048-1064

Badri, H., Monsieurs, P., Coninx, I., Wattiez, R., \& Leys, N. (2015). Molecular investigation of the radiation resistance of edible cyanobacterium Arthrospira sp. PCC 8005. Microbiology Open, 4(2), 187-207.

Báldi, A. (2003). Using higher taxa as surrogates of species richness: A study based on 3700 Coleoptera, Diptera, and Acari species in Central-Hungarian reserves. Basic and Applied Ecology, 4(6), 589-593.

Becker, V., Caputo, L., Ordóñez, J., Marcé, R., Armengol, J., Crossetti, L. O., \& Huszar, V. L. M. (2010). Driving factors of the phytoplankton functional groups in a deep Mediterranean reservoir. Water Research, 44(11), 3345-3354.

Becker, V., Huszar, V. L. M., \& Crossetti, L. O. (2009). Responses of phytoplankton functional groups to the mixing regime in a deep subtropical reservoir. Hydrobiologia, 628(1), 137-151.

Berman, T. (2001). The role of DON and the effect of $\mathrm{N}: \mathrm{P}$ ratios on occurrence of cyanobacterial blooms: Implications from the outgrowth of Aphanizomenon in Lake Kinneret. Limnology and Oceanography, 46(2), 443-447.

Beversdorf, L. J., Miller, T. R., \& McMahon, K. D. (2015). Long-term monitoring reveals carbon-nitrogen metabolism key to microcystin production in eutrophic lakes. Frontiers in Microbiology, 6, 456.

Bláha, L., Babica, P., \& Maršálek, B. (2009). Toxins produced in cyanobacterial water blooms - toxicity and risks. Interdisciplinary Toxicology, 2(2), 36-41.

Borcard, D., \& Legendre, P. (2002). All-scale spatial analysis of ecological data by means of principal coordinates of neighbour matrices. Ecological Modelling, 153, 51-68.

Borcard, D., Legendre, P., \& Drapeau, P. (1992). Partialling out the spatial component of ecological variation. Ecology, 73(3), 1045-1055.

Bothe, H., Schmitz, O., Yates, M. G., \& Newton, W. E. (2010). Nitrogen fixation and hydrogen metabolism in Cyanobacteria. Microbiology and Molecular Biology Reviews, 74(4), 529-551.

Bozinovic, F., \& Naya, D. E. (2015). Linking physiology, climate, and species distributional ranges. In: Integrative organismal biology. Wiley Blackwell. Pp. 277-290.

Bozinovic, F., Calosi, P., \& Spicer, J. I. (2011). Physiological correlates of geographic range in animals. Annual Review of Ecology, Evolution, and Systematics, 42(1), 155-179.

Brookes, J. D., \& Carey, C. C. (2011). Ecology: Resilience to blooms. Science, 334(6052), 46-47.

Callieri, C., \& Stockner, J. (2000). Picocyanobacteria success in oligotrophic lakes: Fact or fiction? Journal of Limnology, 59(1), 72-76.

Carey, C. C., Ibelings, B. W., Hoffmann, E. P., Hamilton, D. P., \& Brookes, J. D. (2012). Eco-physiological adaptations that favour freshwater cyanobacteria in a changing climate. Water Research, 46(5), 1394-1407.

Červený, J., Sinetova, M. A., Zavřel, T., \& Los, D. A. (2015). Mechanisms of high temperature resistance of Synechocystis sp. PCC 6803: An impact of histidine kinase 34. Life, 5(1), 676-699.

Chittora, D., Meena, M., Barupal, T., \& Swapnil, P. (2020). Cyanobacteria as a source of biofertilizers for sustainable agriculture. Biochemistry and Biophysics Reports, 22, 100737.

Cho, J. C., \& Tiedje, J. M. (2000). Biogeography and degree of endemicity of fluorescent Pseudomonas strains in soil. Applied and Environmental Microbiology, 66(12), 5448-5456. 
Coad, P., Cathers, B., Ball, J. E., \& Kadluczka, R. (2014). Proactive management of estuarine algal blooms using an automated monitoring buoy coupled with an artificial neural network. Environmental Modelling and Software, 61, 393-409.

Codd, G. A., Morrison, L. F., \& Metcalf, J. S. (2005). Cyanobacterial toxins: Risk management for health protection. Toxicology and Applied Pharmacology, 203(3), 264-272.

Codd, G., Bell, S., Kaya, K., Ward, C., Beattie, K., \& Metcalf, J. (1999) Cyanobacterial toxins, exposure routes and human health. European Journal of Phycology, 34(4), 405-415.

Costa, L. S., Huszar, V. L. M., \& Ovalle, A. R. (2009). Phytoplankton functiona groups in a tropical estuary: Hydrological control and nutrient limitation. Estuaries and Coasts, 32(3), 508-521.

Cupertino, A., Gücker, B., Von Rückert, G., \& Figueredo, C. C. (2019). Phytoplankton assemblage composition as an environmental indicator in routine lentic monitoring: Taxonomic versus functional groups. Ecological Indicators, 101, 522-532.

Dadheech, P. K., Selmeczy, G. B., Vasas, G., Pádisak, J., Arp, W., Tapolczai, K., Casper, P., \& Krienitz, L. (2014). Presence of potential toxin-producing cyanobacteria in an oligo-mesotrophic lake in Baltic lake district, Germany: An ecological, genetic and toxicological survey. Toxins, 6(10), 2912-2931.

Davidson, K., Gowen, R. J., Harrison, P. J., Fleming, L. E., Hoagland, P., \& Moschonas, G. (2014). Anthropogenic nutrients and harmful algae in coastal waters. Journal of Environmental Management, 146, 206-216.

Downing, J. A., Watson, S. B., \& McCauley, E. (2001). Predicting Cyanobacteria dominance in lakes. Canadian Journal of Fisheries and Aquatic Sciences, 58(10), 1905-1908

Enquist, B. J., Haskell, J. P., \& Tiffney, B. H. (2002). General patterns of taxonomic and biomass partitioning in extant and fossil plant communities. Nature, 419(6907), 610-613.

Fierer, N., \& Jackson, R. B. (2006). The diversity and biogeography of soil bacterial communities. Proceedings of the National Academy of Sciences of the United States of America, 103(3), 626-631.

Fischer, M. M. (2019). Quantifying the uncertainty of variance partitioning estimates of ecological datasets. Environmental and Ecological Statistics, 26(4), 351-366.

Fisher, R. A., Corbet, A. S., \& Williams, C. B. (1943). The relation between the number of species and the number of individuals in a random sample of an animal population. The Journal of Animal Ecology, 12(1), 42

Flombaum, P., Gallegos, J. L., Gordillo, R. A., Rincón, J., Zabala, L. L., Jiao, N., Karl, D. M., Li, W. K. W., Lomas, M. W., Veneziano, D., Vera, C. S., Vrugt, J. A., \& Martiny, A. C. (2013). Present and future global distrib6utions of the marine Cyanobacteria Prochlorococcus and Synechococcus. Proceedings of the National Academy of Sciences of the United States of America, 110(24), 9824-9829.

Foissner, W. (2006). Biogeography and dispersal of micro-organisms: A review emphasizing protists. Acta Protozoologica, 45, 111-136.

Fuchsman, C. A., Palevsky, H. I., Widner, B., Duffy, M., Carlson, M. C. G., Neibauer, J. A., Mulholland, M. R., Keil, R. G., Devol, A. H., \& Rocap, G. (2019). Cyanobacteria and cyanophage contributions to carbon and nitrogen cycling in an oligotrophic oxygen-deficient zone. ISME Journal, 13(11), 2714 2726

Gilbert, B., \& Bennett, J. R. (2010). Partitioning variation in ecological communities: Do the numbers add up? Journal of Applied Ecology, 47(5), 1071-1082.

Gleason, H. A. (1922). On the relation between species and area. Ecology, 3(2), $158-162$

Glockner, F. O., Zaichikov, E., Belkova, N., Denissova, L., Pernthaler, J., Pernthaler, A., \& Amann, R. (2000). Comparative 16S rRNA analysis of lake bacterioplankton reveals globally distributed phylogenetic clusters including an abundant group of Actinobacteria. Applied and Environmental Microbiology, 66(11), 5053-5065.

Gongalsky, K. B. (2014). Wildfires and soil fauna. KMK Scientific Press Ltd, Moscow.

Hamilton, T. L., Bryant, D. A., \& Macalady, J. L. (2016). The role of biology in planetary evolution: Cyanobacterial primary production in low-oxygen Proterozoic oceans. Environmental Microbiology, 18(2), 325-340.

Hoffman, L. (1999). Marine cyanobacteria in tropical regions: Diversity and ecology. European Journal of Phycology, 34(4), 371-379.

Hoffmann, L. (1996). Geographic distribution of freshwater blue-green algae. Hydrobiologia, 336, 33-40.

Hollerbach, M. M., \& Stina, E. A. (1969). Soil algae. Science, Leningrad.

Inoue, N., Taira, Y., Emi, T., Yamane, Y., Kashino, Y., Koike, H., \& Satoh, K (2001). Acclimation to the growth temperature and the high-temperatureeffects on photosystem II and plasma membranes in a mesophilic cyanobacterium, Synechocystis sp. PCC6803. Plant and Cell Physiology, 42(10), 1140-1148.

Ionescu, D., Hindiyeh, M., Malkawi, H., \& Oren, A. (2010). Biogeography of thermophilic cyanobacteria: Insights from the Zerka Ma'in hot springs (Jordan). FEMS Microbiology Ecology, 72(1), 103-113.

Jiang, Y. L., Wang, X. P., Sun, H., Han, S. J., Li, W. F., Cui, N., Lin, G. M., Zhang, J. Y., Cheng, W., Cao, D. D., Zhang, Z. Y., Zhang, C. C., Chen, Y., \& Zhou,
C.Z. (2017). Coordinating carbon and nitrogen metabolic signaling through the cyanobacterial global repressor NdhR. Proceedings of the National Academy of Sciences of the United States of America, 115(2), 403-408

Jungblut, A. D., Lovejoy, C., \& Vincent, W. F. (2010). Global distribution of cyanobacterial ecotypes in the cold biosphere. ISME Journal, 4(2), 191-202.

Kimambo, O. N., Gumbo, J. R., \& Chikoore, H. (2019). The occurrence of cyanobacteria blooms in freshwater ecosystems and their link with hydro-meteorological and environmental variations in Tanzania. Heliyon, 5(3), e01312.

Kitahara, R., Oyama, K., Kawamura, T., Mitsuhashi, K., Kitazawa, S., Yasunaga, K, Sagara, N., Fujimoto, M., \& Terauchi, K. (2019). Pressure accelerates the circadian clock of cyanobacteria. Scientific Reports, 9(1), 1-8.

Kokociński, M., Stefaniak, K., Mankiewicz-Boczek, J., Izydorczyk, K., \& Soininen, J. (2010). The ecology of the invasive cyanobacterium Cylindrospermopsis raciborskii (Nostocales, Cyanophyta) in two hypereutrophic lakes dominated by Planktothrix agardhii (Oscillatoriales, Cyanophyta). European Journal of Phycology, 45(4), 365-374.

Komárek, J., \& Anagnostidis, K. (1999). Cyanoprokaryota. I. Chroococcales. Spektrum, Akademischer Verlag, Heidelberg, Berlin

Kraus, M. P. (1969). Resistance of blue-green algae to ${ }^{60} \mathrm{Co}$ gamma radiation. Radiation Botany, 9(6), 481-489.

Kruk, C., Devercelli, M., Huszar, V. L. M., Hernández, E., Beamud, G., Diaz, M, Silva, L. H. S., \& Segura, A. M. (2017). Classification of Reynolds phytoplankton functional groups using individual traits and machine learning techniques. Freshwater Biology, 62(10), 1681-1692.

Legendre, P. (2007). Studying beta diversity: Ecological variation partitioning by multiple regression and canonical analysis. Chinese Journal of Plant Ecology, 31(5), 976-981

Legendre, P., Borcard, D., \& Peres-Neto, P. R. (2005). Analyzing beta diversity: Partitioning the spatial variation of community composition data. Ecologica Monographs, 75(4), 435-450.

Liu, X., Hou, W., Dong, H., Wang, S., Jiang, H., Wu, G., Yang, J., \& Li, G. (2016) Distribution and diversity of cyanobacteria and eukaryotic algae in QinghaiTibetan Lakes. Geomicrobiology Journal, 33(10), 860-869.

Lopes, V. R., \& Vasconcelos, V. M. (2011). Planktonic and benthic cyanobacteria of European brackish waters: A perspective on estuaries and brackish seas. European Journal of Phycology, 46(3), 292-304

Lürling, M., e Mello, M. M., van Oosterhout, F., de Senerpont Domis, L., \& Marinho, M. M. (2018). Response of natural cyanobacteria and algae assemblages to a nutrient pulse and elevated temperature. Frontiers in Microbiology, 9,1851

Machado, K. B., Borges, P. P., Carneiro, F. M., de Santana, J. F., Vieira, L. C. G., de Moraes Huszar, V. L., \& Nabout, J. C. (2015). Using lower taxonomic resolution and ecological approaches as a surrogate for plankton species. Hydrobiologia, 743(1), 255-267.

Maltseva, I., Yarova, T., Arabadzhi-Tipenko, L., Pavlenko, O., Yakoviichuk, O., Zinenko, A., \& Manuilova, M. (2019). Innovative technologies for ensuring ecological safety of maritime recreation. In: Ekkert, M., Nestorenko, O., \& Szynk, M. (Eds.). Modem innovative and information technologies in the development of society. Wydawnictwo Wyższej Szkoły Technicznej w Katowicach, Katowice. Pp. 29-38

Martiny, J. B. H., Bohannan, B. J. M., Brown, J. H., Colwell, R. K., Fuhrman, J. A Green, J. L., Horner-Devine, M. C. Kane, M., Krumins, J. A., Kuske, C. R. Morin, P. J., Naeem, S., Øvreås, L., Reysenbach, A. L., Smith, V. H., \& Staley, J. T. (2006). Microbial biogeography: Putting microorganisms on the map. Nature Reviews Microbiology, 4(2), 102-112.

Miller, S. R., Castenholz, R. W., \& Pedersen, D. (2007). Phylogeography of the thermophilic cyanobacterium Mastigocladus laminosus. Applied and Environmental Microbiology, 73(15), 4751-4759.

Mullins, T. D., Britschgi, T. B., Krest, R. L., \& Gioivannoni, S. J. (1995). Genetic comparisons reveal the same unknown bacterial lineages in Atlantic and Pacific bacterioplankton communities. Limnology and Oceanography, 40(1), 148-158.

Napiórkowska-Krzebietke, A., \& Hutorowicz, A. (2013). A comparison of epilimnetic versus metalimnetic phytoplankton assemblages in two mesotrophic lakes. Oceanological and Hydrobiological Studies, 42(1), 89-98.

Nixdorf, B., \& Deneke, R. (1997). Why 'very shallow' lakes are more successful opposing reduced nutrient loads. Hydrobiologia, 342/343, 269-284.

Padisák, J., Crossetti, L. O., \& Naselli-Flores, L. (2009). Use and misuse in the application of the phytoplankton functional classification: A critical review with updates. Hydrobiologia, 621(1), 1-19.

Palmer, M. W., McGlinn, D. J., \& Fridley, J. D. (2008). Artifacts and artifictioxns in biodiversity research. Folia Geobotanica, 43(3), 245-257.

Pankratova, E. M. (2006). Functioning of cyanobacteria in soil ecosystems. Eurasian Soil Science, 39(S1), S118-S127.

Papke, R. T., Ramsing, N. B., Bateson, M. M., \& Ward, D. M. (2003). Geographical isolation in hot spring cyanobacteria. Environmental Microbiology, 5(8), 650-659.

Pearson, T., Giffard, P., Beckstrom-Sternberg, S., Auerbach, R., Hornstra, H Tuanyok, A., Price, E. P., Glass, M. B., Leadem, B., Beckstrom-Sternberg, J. S., 
Allan, G. J., Foster, J. T., Wagner, D. M., Okinaka, R. T., Sim, S. H., Pearson, O., Wu, Z., Chang, J., Kaul, R., Hoffmaster, A. R., Brettin, T. S., Robison, R. A., Mayo, M., Gee, J. E., Tan, P., Currie, B. J., \& Keim, P. (2009) Phylogeographic reconstruction of a bacterial species with high levels of lateral gene transfer. BMC Biology, 7(1), 78.

Pełechata, A., Pelechaty, M., \& Pukacz, A. (2016). Factors influencing cyanobacteria community structure in Chara-lakes. Ecological Indicators, 71, 477-490.

Pither, J. (2003). Climate tolerance and interspecific variation in geographic range size. Proceedings of the Royal Society of London. Series B: Biological Sciences, 270(1514), 475-481.

Pokarzhevskii, A. D. (1996). The problem of scale in bioindication of soil contamination. In: Krivolutsky, D. A., \& van Straalen, N. M. (Eds.). Bioindicator systems for soil pollution. Kluwer Academic Publishers, Dordrecht. Pp. 111-121.

Posch, T., Köster, O., Salcher, M. M., \& Pernthaler, J. (2012). Harmful filamentous cyanobacteria favoured by reduced water turnover with lake warming. Nature Climate Change, 2(11), 809-813.

Qin, L., Yu, Q., Ai, W., Tang, Y., Ren, J., \& Guo, S. (2014). Response of cyanobacteria to low atmospheric pressure. Life Sciences in Space Research, 3, 55-62.

Ramette, A., \& Tiedje, J. M. (2007). Biogeography: An emerging cornerstone for understanding prokaryotic diversity, ecology, and evolution. Microbial Ecology, 53(2), 197-207.

Rampelotto, P.H.(2013). Extremophiles and extreme environments. Life, 3(3), 482-485.

Rastogi, R. P., Madamwar, D., \& Incharoensakdi, A. (2015). Bloom dynamics of cyanobacteria and their toxins: Environmental health impacts and mitigation strategies. Frontiers in Microbiology, 6, 1254.

Reynolds, C. S. (1984). The ecology of freshwater phytoplankton. Cambridge University, Cambridge, UK.

Reynolds, C. S., Huszar, V., Kruk, C., Naselliflores, L., \& Melo, S. T. (2002). Towards a functional classification of the freshwater phytoplankton. Journal of Plankton Research, 24(5), 417-428.

Rodrigues, L. C., Pivato, B. M., Vieira, L. C. G., Bovo-Scomparin, V. M., Bortolini, J. C., Pineda, A., \& Train, S. (2018). Use of phytoplankton functional groups as a model of spatial and temporal patterns in reservoirs: A case study in a reservoir of Central Brazil. Hydrobiologia, 805(1), 147-161.

Santana, L. M., Crossetti, L. O., \& Ferragut, C. (2017). Ecological status assessment of tropical reservoirs through the assemblage index of phytoplankton functional groups. Revista Brasileira de Botanica, 40(3), 695-704.

Sattler, T., Borcard, D., Arlettaz, R., Bontadina, F., Legendre, P., Obrist, M. K., \& Moretti, M. (2010). Spider, bee, and bird communities in cities are shaped by environmental control and high stochasticity. Ecology, 91(11), 3343-3353.

Shi, Y., Grogan, P., Sun, H., Xiong, J., Yang, Y., Zhou, J., \& Chu, H. (2015). Multiscale variability analysis reveals the importance of spatial distance in shaping arctic soil microbial functional communities. Soil Biology and Biochemistry, $86,126-134$.

Singh, J. S., Kumar, A., Rai, A. N., \& Singh, D. P. (2016). Cyanobacteria: A precious bio-resource in agriculture, ecosystem, and environmental sustainability. Frontiers in Microbiology, 7, 529.

Smith, T. W., \& Lundholm, J. T. (2010). Variation partitioning as a tool to distinguish between niche and neutral processes. Ecography, 33(4), 648-655.

Smith, V. H. (1983). Low nitrogen to phosphorus ratios favor dominance by bluegreen algae in lake phytoplankton. Science, 221(4611), 669-671.

Sokolov, S. G., \& Zhukov, A. V. (2017). Functional diversity of a parasite assemblages of the Chinese sleeper Perccottus glenii Dybowski, 1877 (Actinopterygii: Odontobutidae) and habitat structure of the host. Biology Bulletin, 44(3), 331-336.

Sommer, U., Gliwicz, Z. M., Lampert, W., \& Duncan, A. K. (1986). The PEGmodel of seasonal succession of planktonic events in fresh waters. Archiv Fur Hydrobiologie, 86, 433-471.

Spicer, J., \& Gaston, K. (2009). Physiological diversity: Ecological implications. John Wiley \& Sons.

Ter Braak, C. J. F., \& Prentice, I. C. (1988). A theory of gradient analysis. Advances in Ecological Research, 18(C), 271-317.

Tonkin, J. D., Heino, J., Sundermann, A., Haase, P., \& Jähnig, S. C. (2016). Context dependency in biodiversity patterns of central German stream metacommunities. Freshwater Biology, 61(5), 607-620.

Van Der Gucht, K., Cottenie, K., Muylaert, K., Vloemans, N., Cousin, S., Declerck, S., Jeppesen, E., Conde-Porcuna, J. M., Schwenk, K., Zwart, G., Degans, H., Vyverman, W., \& De Meester, L. (2007). The power of species sorting: Local factors drive bacterial community composition over a wide range of spatial scales. Proceedings of the National Academy of Sciences of the United States of America, 104(51), 20404-20409.

van Gremberghe, I., Leliaert, F., Mergeay, J., Vanormelingen, P., van der Gucht, K., Debeer, A. E., Lacerot, G., de Meester, L., \& Vyverman, W. (2011). Lack of phylogeographic structure in the freshwater cyanobacterium Microcystis aeruginosa suggests global dispersal. PLoS One, 6(5), 19561.

Varshney, P., Mikulic, P., Vonshak, A., Beardall, J., \& Wangikar, P. P. (2015). Extremophilic micro-algae and their potential contribution in biotechnology. Bioresource Technology, 184, 363-372.

Vinigradova, O. (2012). Cyanoprokaryota in hyperhaline ecosystems of Ukraine. Alterpres, Kyiv.

Vinogradova, O. M. (2006). Cyanoprocaryota in hypergaline habitats and their adaptation strategies. Ukrainian Phytocenological Collection, 24, 33- 44.

Vinogradova, O., \& Bryantseva, Y. (2017). Taxonomic revision of the species composition of Cyanobacteria/Cyanoprokaryota of the Ukrainian coast of the Black Sea. Algologia, 27(4), 436-457.

Vorovka, V. P. (2011). Landscape diversity of the Priazovk National Nature Park. Bulletin of the Donetsk Institute of Social Education, 7(7), 24-27.

Wagner, C., \& Adrian, R. (2009). Cyanobacteria dominance: Quantifying the effects of climate change. Limnology and Oceanography, 54(6), 2460-2468.

Walter, J. M., Lopes, F. A. C., Lopes-Ferreira, M., Vidal, L. M., Leomil, L., Melo, F., de Azevedo, G. S., Oliveira, R. M. S., Medeiros, A. J., Melo, A. S. O., De Rezende, C. E., Tanuri, A., \& Thompson, F. L. (2018). Occurrence of harmful cyanobacteria in drinking water from a severely drought-impacted semi-arid region. Frontiers in Microbiology, 9, 176.

Webb, C. O., Ackerly, D. D., McPeek, M. A., \& Donoghue, M. J. (2002). Phylogenies and community ecology. Annual Review of Ecology and Systematics, 33, 475-505.

Whitaker, R. J. (2006). Allopatric origins of microbial species. Philosophical Transactions of the Royal Society B: Biological Sciences, 361(1475), 1975-1984

Whitaker, R. J., Grogan, D. W., \& Taylor, J. W. (2003). Geographic barriers isolate endemic populations of hyperthermophilic Archaea. Science, 301(5635), 976-978.

Wiedner, C., Nixdorf, B., Heinze, R., Wirsing, B., Neumann, U., \& Weckesser, J. (2002). Regulation of cyanobacteria and microcystindynamics in polymictic shallow lakes. Archiv Für Hydrobiologie, 155(3), 383-400.

Yao, L., Zhao, X., Zhou, G. J., Liang, R., Gou, T., Xia, B., Li, S., \& Liu, C. (2020). Seasonal succession of phytoplankton functional groups and driving factors of cyanobacterial blooms in a subtropical reservoir in South China. Water (Switzerland), 12(4), 1167.

Yatagai, F., \& Ishioka, N. (2014). Are biological effects of space radiation really altered under the microgravity environment? Life Sciences in Space Research, 3, 76-89.

Yorkina, N., Maslikova, K., Kunah, O., \& Zhukov, O. (2018). Analysis of the spatial organization of Vallonia pulchella (Muller, 1774) ecological niche in Technosols (Nikopol manganese ore basin, Ukraine). Ecologica Montenegrina, 17, 29-45.

Yorkina, N., Zhukov, O., \& Chromysheva, O. (2019). Potential possibilities of soil mesofauna usage for biodiagnostics of soil contamination by heavy metals. Ekologia Bratislava, 38(1), 1-10.

Zhang, C. C., Zhou, C. Z., Burnap, R. L., \& Peng, L. (2018). Carbon/nitrogen metabolic balance: Lessons from Cyanobacteria. Trends in Plant Science, 23(12), 1116-1130.

Zhang, M., Qin, B., Yu, Y., Yang, Z., Shi, X., \& Kong, F. (2016). Effects of temperature fluctuation on the development of cyanobacterial dominance in spring: Implication of future climate change. Hydrobiologia, 763(1), 135-146.

Zhukov, O., Kunah, O., Dubinina, Y., \& Novikova, V. (2018). The role of edaphic and vegetation factors in structuring beta diversity of the soil macrofauna community of the Dnipro river arena terrace. Ekológia (Bratislava), 37(3), 301-327.

Zohary, T., \& Breen, C. M. (1989). Environmental factors favouring the formation of Microcystis aeruginosa hyperscums in a hypertrophic lake. Hydrobiologia, 178(3), 179-192.

Zwirglmaier, K., Jardillier, L., Ostrowski, M., Mazard, S., Garczarek, L., Vaulot, D., Not, F., Massana, R., Ulloa, O., \& Scanlan, D. J. (2008). Global phylogeography of marine Synechococcus and Prochlorococcus reveals a distinct partitioning of lineages among oceanic biomes. Environmental Microbiology, 10(1), 147-161. 